\title{
Sistem Pendukung Keputusan Kelayakan Penerimaan Bantuan Beras Sejahtera (Rastra) Dengan Menggunakan Metode Weighted Product
}

\author{
Sukril I. Wahid \\ Program Studi Teknik Informatika \\ Universitas Khairun \\ Ternate, Indonesia \\ Ilex.cakle@gmail.com
}

\author{
Moh. Jamil \\ Program Studi Teknik Informatika \\ Universitas Khairun \\ Ternate, Indonesia \\ Jamil@unkhair.ac.id
}

\author{
Firman Tempola \\ Program Studi Teknik Informatika \\ Universitas Khairun \\ Ternate, Indonesia \\ Firman.tempola@unkhair.ac.id
}

\begin{abstract}
Beras Sejahtera (RASTRA) program is a government policy in the context of community empowerment so that a prosperous society that has been running for a long time, but in its implementation the Literature program still occurs many deviations such as not on target, not on time, and sometimes rice is lacking suitable for consumption, this is often the case in the village office of Tabam in North Ternate City, North Maluku Province. In accordance with the provisions which have the right or not received assistance, a Decision Support System (DSS) is needed. Decision support systems can help decision making in semitructured situations and unstructured situations, where no one knows for sure how decisions should be made. In this study using the Weighted Product method. From the results of the study showed the use of Weighted Product as a Supporting System Model for Decision on Acceptability of Literature Acceptance with Weighted Product method in village office of tabam, North Ternate City can assist the village office in calculating the feasibility of prospective beneficiaries of Prosperous Rice and to determine the feasibility of poor rice recipients to be more targeted and storage selection data can be updated at any time.
\end{abstract}

Keywords- Beras Sejahtera; DSS; Weighted Product

\section{PENDAHULUAN}

Kemiskinan merupakan salah satu masalah yang sampai saat ini belum bisa teratasi Hampir di semua negara berkembang mengalami masalah kemiskinan, terutama pada negara yang padat penduduk seperti di Indonesia. Pemerintah telah mengeluarkan berbagai langkah dan kebijakan untuk menangulangi kemiskinan di Indonesia, salah satunya program Beras Sejahtera (Rastra) yang masih berjalan sampai saat ini.
Secara umum permasalahan yang terjadi pada pemberian Rastra (Beras Sejahtera) pada Kantor Lurah Tabam Kota Ternate Utara masih belum optimal, karena pada saat pemilihan penerima bantuan belum ada sistem yang mendukung sehingga pada saat proses pemilihan masih menggunakan perkiraan saja dan belum adanya perhitungan pada saat pemilihan penerima bantuan tersebut. Sehingga sedikit atau banyaknya warga terkadang protes karena warga yang seharusnya mendapatkan bantuan tetapi mereka tidak mendapatkan bantuan tersebut, begitupun sebaliknya.

Sebelumnya untuk masalah kesejahteraan sosial pernah dilakukan oleh [1] yaitu untuk pemberiaan Program Keluarga Harapan di Kota Ternate menggunakan metode AHPdengan judul "Sistem Pendukung Keputusan Pemberian Bantuan Program Keluarga Harapan (PKH) Pada Orang Miskin Di Kota Ternate Menggunakan Metode AHP",[2] membuat SPK untuk pemenang Tender menggunakan metode bayes dan group technology. [3] mengkombinasikan fuzzy dan naive bayes untuk pendukung keputusan UKT.

Sistem Pendukung Keputusan (SPK) bertujuan untuk memberikan rekomendasi dalam pengambilan keputusan dengan lebih cepat dan akurat [4] Sesuai dengan ketentuan mana yang berhak mendapatkan bantuan, diperlukan kriteriakriteria yang digunakan berupa jenis pekerjaan, jumlah penghasilan, jumlah tanggungan, kondisi rumah,kepemilikan rumah, jaringan listrik, sumber air, dan umur. Pada penelitian ini metode yang digunakan adalah Weighted Product (WP). Metode WP merupakan suatu metode penentuan urutan (prioritas) dalam analisis multikriteria dan menggunakan teknik perkalian untuk menghubungkan rating atribut, dimana rating tiap atribut harus dipangkatkan terlebih dahulu dengan bobot atribut yang bersangkutan.

Dengan pemanfaatan SPK (Sistem Pendukung Keputusan) dalam pengambilan keputusan pemberian bantuan RASTRA (Beras Sejahtera) di Kota Ternate Utara diharapkan dapat membantu Kantor Kelurahan Tabam dalam mengambil keputusan untuk pemberian bantuan kepada orang miskin agar 
lebih tepat dan terarah. Berdasarkan pemikiran tersebut penulis mencoba untuk membuat "Sistem Pendukung Keputusan Kelayakan Penerimaan Bantuan Beras Sejahtera (Rastra) dengan Menggunakan Metode Weighted Product di Kelurahan Tabam Kota Ternate Utara.

\section{METODE PENELITIAN}

2.1. Sistem Pendukung Keputusan

Sistem Pendukung Keputusan merupakan sistem informasi interaktif yang menyediakan informasi, pemodelan, dan pemanipulasian data. Sistem itu digunakan untuk membantu pengambilan keputusan dalam situasi yang semiterstruktur dan situasi yang tidak terstruktur, dimana tak seorangpun tahu secara pasti bagaimana keputusan seharusnya dibuat. SPK dibangun untuk mendukung solusi atas suatu masalah atau untuk mengevaluasi suatu peluang. Aplikasi SPK menggunakan sistem informasi berbasis komputer yang fleksibel, interaktif, dan dapat diadaptasi, yang dikembangkan untuk mendukung solusi atas masalah manajemen spesifik yang tidak terstruktur.

\subsection{Metode Weighted Product (WP)}

Metode Weighted product merupakan metode untuk menyelesaikan Multi Attribute Decision Making (MADM). Weighted Product menggunakan teknik perkalian untuk menghubungkan rating attribute, di mana rating tiap atribut harus di pangkatkan terlebih dahulu dengan atribut bobot yang bersangkutan. Langkah-langkah yang dilakukan dalam penyelesaian masalah menggunakan metode Weighted Produc [5].

a. Normalisasi atau Perbaikan Bobot.

$W_{J}=\frac{W_{j}}{\sum W_{j}}$

Keterangan:

WJ: Nilai Perbaikan Bobot

Wj: Nilai Bobot

$\sum_{\mathrm{Wj}}$ : Total Penjumlahan Nilai Bobot

b. Menentukan Nilai Vektor $(s)$

Keterangan:

$$
S_{i}=\prod_{j=1}^{n} X_{i j}^{W j}
$$

Si: nilai preferensi alternatif ke $\mathrm{i}=(1,2,3 \ldots)$

$\Pi$ : produk perkalian

Xij: nilai kriteria ke-j pada alternatif ke-i

$\mathrm{Wj}$ : nilai bobot pada kriteria ke-j

n: banyaknya kriteria

c. Menentukan Nilai Vektor

$V_{i}=\frac{S i}{\sum_{j=1}^{n} S i}$

Keterangan:

$\mathrm{Vi}=$ nilai prefensi relatif pada alternatif ke-i

$\mathrm{Si}=$ nilai prefensi alaternatif ke-i

$\mathrm{n}=$ banyaknya alternatif

\subsection{Program Beras Sejahtera}

Program Beras untuk Keluarga Sejahtera (Program Rastra) merupakan Program Nasional lintas sektoral yang diperuntukkan bagi Keluarga Penerima Manfaat sebagai upaya dari pemerintah untuk meningkatkan ketahanan pangan dan memberikan perlindungan sosial. Dalam pelaksanaanya, pemerintah telah mengambil berbagai kebijakan penyesuaian terhadap kondisi yang berkembang, misalnya penyesuaian Keluarga Penerima Manfaat (KPM) durasi penyaluran, alokasi jumlah beras untuk setiap KPM.

\subsection{Tujuan dan Manfaat Beras Sejahtera}

Adapun tujuan, sasaran dan manfaat Rastra menurut pedum Rastra 2015 adalah (Megayana, 2016):

1. Tujuan Rastra adalah mengurangi beban pengeluaran rumah tangga sasaran melalui pemenuhan sebagian kebutuhan pangan beras.

2. Manfaat Rastra adalah peningkatan ketahanan pengan ditingkat rumah tangga sasaran, sekaligus mekanisme perlindungan sosial dan penanggulangan kemiskininan, peningkatan akses pangan baik secara fisik (beras tersedia di TD), maupun ekonomi (harga jual yang terjangkau) kepada RTS, sebagai pasar bagi hasil usaha tani padi, stabilisasi harga beras di pasaran, pengendalian inflasi melalui intervensi pemerintah dengan menetapkan harga beras bersubsidi sebesar Rp. 1.600,$/ \mathrm{kg}$, dan menjaga stok pangan nasional, serta membantu pertumbuhan ekonomi daerah.

\subsection{Dasar Hukum}

Adapun dasar hukum yang dipakai dalam pelaksanaan pemberian Bantuan Sosial Beras Sejahtera (BANSOS RASTRA) antara lain [6].

1. Undang-Undang Nomor 17 Tahun 2003 tentang Keuangan Negara (Lembaran Negara Republik IndonesiaTahun 2003 Nomor 47, Tambahan Lembaran Negara Republik Nomor 4286).

2. Undang-Undang Nomor 11 Tahun 2009 tentang Kesejahteraan Sosial (Lembaran Negara Republik Indonesia Tahun 2009 Nomor 12, Tambahan Lembaran Negara Republik Indonesia Nomor 4967).

3. Keputusan Menteri Sosial Nomor.../HUK/2017 tentang Penugasan Perum BULOG dalam Pelaksanaan Bansos Rastra.

2.6. Syarat Kepesertaan Penerima Beras Sejahtera Keluarga penerima manfaat (KPM) Rastra adalah keluarga miskin yang memenuhi minimal kriteria sebagai berikut:

1. Jenis Pekerjaan, Pekerjaan yang lebih di prioritaskan adalah Pengangguran, Buruh, nelayan, berkebun.

2. Jumlah Penghasilan, sumber penghasilan kepala rumah tangga adalah pendapatan dibawah Rp.500.000,- per bulan.

3. Jumlah Tanggungan, tanggungan dalam setiap keluarga adalah 4 anak atau lebih. 
4. Kepemilikan Rumah, rumah yang di tempati merupakan kontrakan atau hanya numpang.

5. Kondisi Rumah, kondisi rumah yang di tempati merupakan jenis rumah panggung atau semi permanen.

6. Jaringan Listrik, Sumber penerangan rumah tangga tidak menggunakan listrik.

7. Sumber Air, Sumber air minum berasal dari sumur/mata air tidak terlindungi/sungai/air hujan.

8. Umur, kepala keluarga yang lebih di prioritaskan berumur di atas 40 sampai 50 tahun.

Berdasarkan dari syarat kepesertaan untuk penerima BPJS maka dalam penelitian ini kriteria yang digunakan untuk proses pendukung keputusan di tunjukkan pada Tabel 1.

Tabel 1. Kriteria Penerima Beras Sejahtera

\begin{tabular}{|c|c|c|c|}
\hline No. & Kriteria & Sub Kriteria & $\begin{array}{l}\text { Nilai } \\
\text { liker }\end{array}$ \\
\hline \multirow[t]{4}{*}{1.} & \multirow{4}{*}{$\begin{array}{l}\text { Jenis } \\
\text { Pekerjaan }\end{array}$} & Pengangguran & 4 \\
\hline & & Buruh/Nelayan/Petani & 3 \\
\hline & & Wiraswasta & 2 \\
\hline & & PNS & 1 \\
\hline \multirow[t]{4}{*}{2.} & \multirow{4}{*}{$\begin{array}{l}\text { Jumlah } \\
\text { Penghasilan }\end{array}$} & $<500.000$ & 4 \\
\hline & & $500.000-1.000 .000$ & 3 \\
\hline & & $1000.000-1.500 .000$ & 2 \\
\hline & & $>1.500 .000$ & 1 \\
\hline \multirow[t]{4}{*}{3} & \multirow{4}{*}{$\begin{array}{l}\text { Jumlah } \\
\text { Tanggungan }\end{array}$} & $>4$ anak & 4 \\
\hline & & 3 anak & 3 \\
\hline & & 2 anak & 2 \\
\hline & & 1 atau tidak punya anak & 1 \\
\hline \multirow[t]{3}{*}{4} & \multirow{3}{*}{$\begin{array}{l}\text { Kondisi } \\
\text { Rumah }\end{array}$} & Panggung & 4 \\
\hline & & Semi Permanen & 3 \\
\hline & & Permanen & 2 \\
\hline \multirow[t]{3}{*}{5} & \multirow{3}{*}{$\begin{array}{l}\text { Kepemilikan } \\
\text { rumah }\end{array}$} & Numpang & 4 \\
\hline & & Kontrak & 3 \\
\hline & & Milik sendiri & 2 \\
\hline \multirow[t]{3}{*}{6} & \multirow{3}{*}{$\begin{array}{l}\text { Jaringan } \\
\text { listrik }\end{array}$} & Tidak ada & 4 \\
\hline & & Numpang & 3 \\
\hline & & Milik sendiri & 2 \\
\hline \multirow[t]{3}{*}{7} & \multirow[t]{3}{*}{ Sumber air } & Air sungai & 4 \\
\hline & & Sumur & 3 \\
\hline & & PDAM & 2 \\
\hline \multirow[t]{4}{*}{8} & Umur & $>50$ & 4 \\
\hline & & $40 \mathrm{~s} / \mathrm{d} 50$ tahun & 4 \\
\hline & & $35 \mathrm{~s} / \mathrm{d} 40$ tahun & 2 \\
\hline & & $<35$ tahun & 1 \\
\hline
\end{tabular}

\subsection{Black Box Testing}

Dalam penelitian untuk pengujian aplikasi digunakan black box testing Black Box Testing adalah pengujian aspek fundamental sistem tanpa memperhatikan struktur logika internal perangkat lunak berfungsi dengan benar. Pengujian black box merupakan metode perancangan data uji yang didasarkan pada spesifikasi perangkat lunak. Data di uji dibangkitkan, dieksekusi pada perangkat lunak kemudian keluaran dari perangkat lunak dicek apakah telah sesuai dengan yang diharapkan.
Pengujian black box berfokus pada pengujian persyaratan fungsional perangkat lunak, untuk mendapatkan serangkaian kondisi input yang sesuai dengan persyaratan fungsional suatu program. Pengujian black box berusaha menemukan kesalahan dalam kategori.

\section{HASIL DAN PEMBAHASAN}

\section{1 Implemetasi sistem}

Sistem pendukung keputusan penerimaan beras sejahtera dengan menggunakan metode weight product menggunakan data-data yang ada di kelurahan Tabam Kecamatan Ternate Utara bahasa pemograman yang digunakan adalah menggunakan bahasa PHP dan MySql. Hasil implementasi sistem dapat ditunjukkan pada Gambar 1.

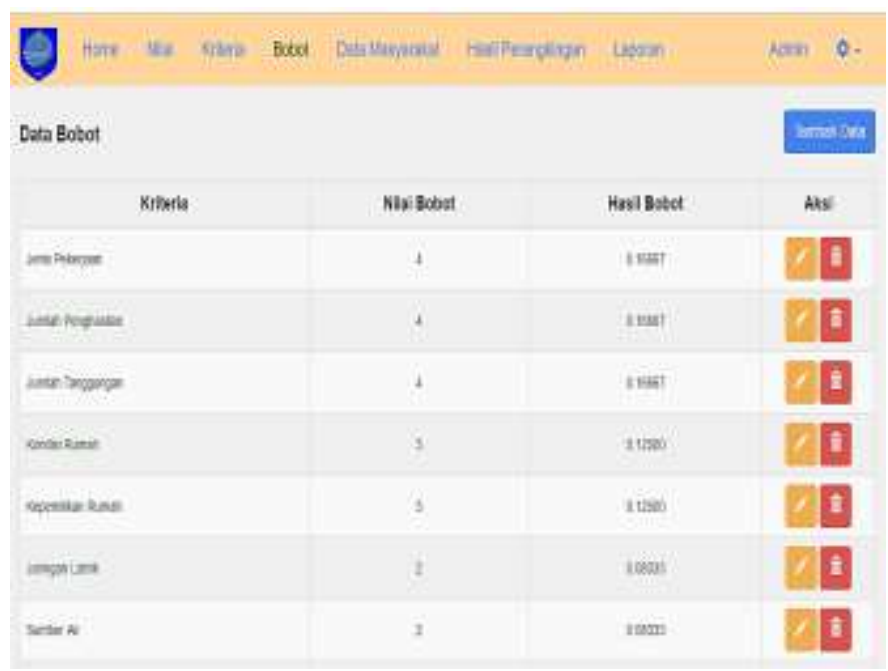

Gambar 1. Hasil implementasi sistem

\section{2 Implemetasi metode weight product}

Untuk menerapkan metode weight product pada sistem pendukung keputusan penerimaan beras sejahtera maka tahap awal adalah data dikumpulkan, pada tabel 1 ditunjukkan beberapa data yang telah dikumpulkan sesuai dengan kriteria dari masing-masing alternatif. Dengan bobot dari masingmasing kriteria adalah $\mathrm{W}=(4,4,4,3,3,2,2,2)$.

Tabel 2. Dataset uji coba metode

\begin{tabular}{|c|c|c|c|c|c|c|c|c|}
\hline \multirow{2}{*}{ ALTERNATIF } & \multicolumn{10}{|c|}{ KRITERIA } \\
\cline { 2 - 10 } & C1 & C2 & C3 & C4 & C5 & C6 & C7 & C8 \\
\hline Ade Hamel & 3 & 3 & 2 & 4 & 2 & 3 & 3 & 3 \\
\hline Manaf Sake & 2 & 3 & 4 & 3 & 3 & 2 & 3 & 2 \\
\hline Rustam Hi. Ali & 4 & 4 & 2 & 4 & 2 & 3 & 4 & 3 \\
\hline
\end{tabular}

Terdapat 2 kategori yang membedakan kriterai-kriteria di atas antara lain.

1. Kriteria C1 (Jenis Pekerjaan), dani C3 (Jumlah Tanggunagn) sampai C8 (Umur) adalah kriteria keuntungan; 
2. Kriteria C2 (Jumlah Penghasilan) adalah kriteria biaya. (Semakin besar nilainya akan semakin buruk).

Untuk menerapkan metode weight product memiliki tahaptahap diantaranya :

1. Normalisasi atau perbaikan bobot.

Berdasarkan hasil normalisasi menggunakan persamaan 1 didapat bobot hasil pebaikan setiap kriteria diantaranya:

$$
\begin{aligned}
& W 1=\frac{4}{4+4+4+3+3+2+2+2}=0,16667 \\
& W 2=\frac{4}{4+4+4+3+3+2+2+2}=0,16667 \\
& W 3=\frac{4}{4+4+4+3+3+2+2+2}=0,16667 \\
& W 4=\frac{3}{4+4+4+3+3+2+2+2}=0,12500 \\
& W 5=\frac{3}{4+4+4+3+3+2+2+2}=0,12500 \\
& W 6=\frac{2}{4+4+4+3+3+2+2+2}=0,08333 \\
& W 7=\frac{2}{4+4+4+3+3+2+2+2}=0,08333 \\
& W 8=\frac{2}{4+4+4+3+3+2+2+2}=0,08333
\end{aligned}
$$

\section{Menghitung vektor $S$}

Hasil hitung vektor S menggunakan Persamaan 2 di dapat hasil dari masing-masing alternatif adalah:

S1

$=\left(3^{0,16667}\right)\left(3^{-0,16667}\right)\left(3^{0,16667}\right)\left(2^{0,12500}\right)\left(2^{0,12500}\right)$

$\left(2^{0,08333}\right)\left(3^{0,08333}\right)\left(4^{0,08333}\right)=1.8611968173$

$\mathrm{S} 2=\left(2^{0,16667}\right)\left(3^{-0,16667}\right)\left(4^{0,16667}\right)\left(2^{0,12500}\right)\left(2^{0,12500}\right)$

$\left(2^{0,08333}\right)\left(3^{0,08333}\right)\left(4^{0,08333}\right)=1.8250161429$

$\mathrm{S} 3=\left(2^{0,16667}\right)\left(3^{-0,16667}\right)\left(4^{0,16667}\right)\left(2^{0,12500}\right)\left(2^{0,12500}\right)$

$\left(2^{0,08333}\right)\left(2^{0,08333}\right)\left(3^{0,08333}\right)=1.9622105443$

\section{Menghitung vektor $\mathrm{V}$}

Tahap ini adalah tahap akhir dalam metode weight product, karena pada tahap ini sudah dapat diketahui nilai akhir dari masing-masing alternatif yang paling prioritas untuk direkomendasikan penerima beras sejahtera. Untuk mendapat nilai vektor $\mathrm{V}$ digunakan Persamaan 3. Dengan hasil yang didapatkan adalah:

$$
\begin{gathered}
\mathrm{V} 1=\frac{1.8612}{1.8612+1.8250+1.7226}=\frac{1.8612}{5.4088} \\
=0.3441059015 \\
\mathrm{~V} 2=\frac{1.8250}{1.8612+1.8250+1.7226}=\frac{1.8250}{5.4088} \\
=0.3374131040
\end{gathered}
$$

$$
\mathrm{V} 3=\frac{1.7226}{1.8612+\begin{array}{c}
1.8250+1.7226 \\
=0.3184809939
\end{array}}=\frac{1.7226}{5.4088}
$$

Dari hasil perhitungan di atas, Nilai V1 menunjukkkan nilai terbesar sehingga dengan kata lain V1 merupakan pilihan alternatif yang terbaik, Keluarga Rustam Hi. Ali layak menjadi pilihan terbaik sesuai dengan pembobotan yang diberikan oleh pengambil keputusan.

\section{3 Implemetasi sistem dan metode weight product}

Pada Gambar 2 ditunjukkan hasil penerapan metode weight product dengan menggunakan bahasa pemograman web dengan mysql. Dimana hasil tersebut sesuai dengan yang dihitung secara manual.

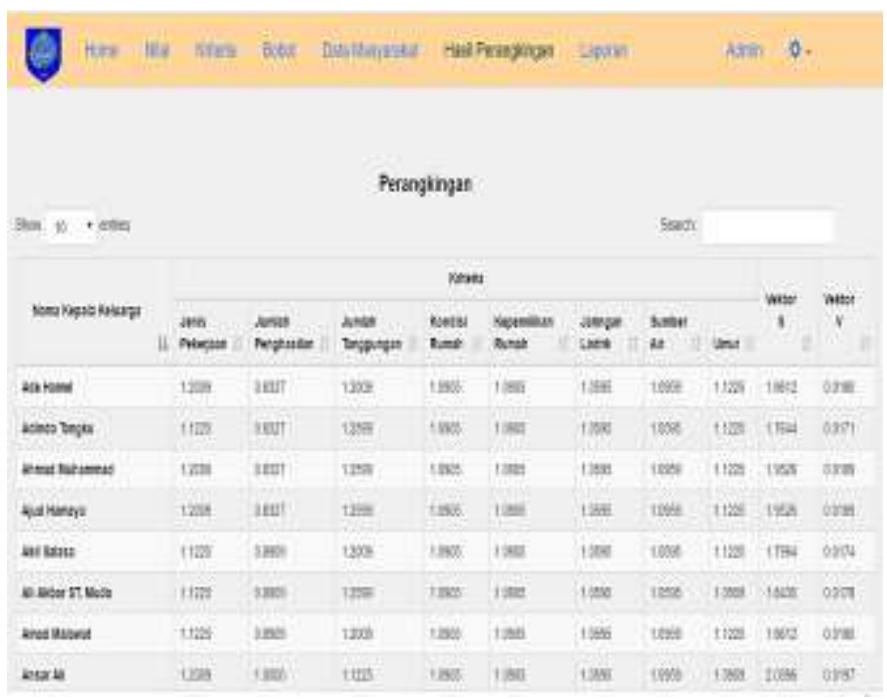

Gambar 2. Hasil implementasi sistem dan metode

\section{4 Pengujian perangkat lunak dengan black box testing}

Tujuan dari pengujian ini adalah untuk menjamin bahwa perangkat lunak yang dibangun memiliki kualitas yang handal yaitu mampu mempresentasikan kajian pokok dari spesifikasi, analisis, perancangan dan pengkodean dari perangkat lunak itu sendiri. Berdasarkan hasil pengujian dengan black box testing sistem dapat berjalan sesuai dengan fungsinya masing-masing.

\section{KESIMPULAN}

Dari hasil perancangan dan pembuatan sistem pendukung keputusan Kelayakan penerima Rastra dengan metode Weighted Product dapat disimpulkan bahwa sistem pendukung keputusan kelayakan penerima Rastra dengan metode Weighted Product berhasil dibuat, dan sistem ini dapat menghasilkan bahan pertimbangan dalam rekomendasi bagi penerima Rastra. Pengujian sistem berdasarkan perhitungan manual, dan perhitungan yang dilakukan oleh sistem terbukti sama sehingga pada aplikasi yang dibangun ini dapat berjalan dengan baik. Pengujian Black Box berjalan sesuai sebagaimana yang diharapkan pada pengujian sistem yang di lakukan. 


\section{DAFTAR PUSTAKA}

[1] Akbar Riodano Laisouw. Salkin Lutfi dan Firman Tempola, "Sistem Pendukung Keputusan Pemberian Bantuan Program Keluarga Harapan ( PKH )," vol. 3, no. 1, pp. 17-29, 2019.

[2] LA Latif, SH Abbas; M Jamil, "Pengembangan Aplikasi Sistem Pendukung Keputusan Berbasis Web Dalam Penentuan Pemenang Tender Menggunakan Metode Bayes dan Group Technology," J. Penelit. pos dan Inform., vol. 7, no. 1, pp. 73-82, 2017.

[3] Anas A, F Tempola dan A Khairan, "Hybrid fuzzy dan Naive Bayes Dalam Penentuan Status UKT," Protek, vol. 06, no. 1, pp. 6-11, 2019.

[4] Turban; Aronson; and Liang, Decision Support System and Intelligent System, Seventh. USA: Prentice Hall, 2005.

[5] Sri Kusumadewi. dkk, Fuzzy Multi-Attribute Decision Making. Yogyakarta: Graha Ilmu, 2006.

[6] Undang-Undang Nomor 17 Tahun 2003 dam Nomor 11 tahun 2009 